Review

\title{
Bone Health in Patients with Dyslipidemias: An Underestimated Aspect
}

\author{
Panagiotis Anagnostis ${ }^{1, *}$, Matilda Florentin ${ }^{2}\left(\mathbb{D}\right.$, Sarantis Livadas ${ }^{3}$, Irene Lambrinoudaki ${ }^{4}$ \\ and Dimitrios G. Goulis ${ }^{1}$ (D)
}

1 Unit of Reproductive Endocrinology, 1st Department of Obstetrics and Gynecology, Medical School, Aristotle University of Thessaloniki, 56429 Thessaloniki, Greece; dimitrios.goulis@gmail.com

2 Department of Internal Medicine, University Hospital of Ioannina, School of Health Sciences, University of Ioannina, 45110 Ioannina, Greece; matildaflorentin@yahoo.com

3 Endocrine Unit, Metropolitan Hospital, 18547 Athens, Greece; sarntis@gmail.com

4 2nd Department of Obstetrics and Gynecology, Medical School, National and Kapodistrian University of Athens, 11528 Athens, Greece; ilambrinoudaki@hotmail.com

* Correspondence: pan.anagnostis@gmail.com; Tel.: +30-2310-257150; Fax: +30-2310-281179

Citation: Anagnostis, P.; Florentin, M.; Livadas, S.; Lambrinoudaki, I.; Goulis, D.G. Bone Health in Patients with Dyslipidemias: An

Underestimated Aspect. Int. J. Mol. Sci. 2022, 23, 1639. https://doi.org/ $10.3390 /$ ijms23031639

Academic Editor: Chih-Hsin Tang

Received: 9 January 2022

Accepted: 28 January 2022

Published: 31 January 2022

Publisher's Note: MDPI stays neutral with regard to jurisdictional claims in published maps and institutional affiliations.

Copyright: (C) 2022 by the authors. Licensee MDPI, Basel, Switzerland. This article is an open access article distributed under the terms and conditions of the Creative Commons Attribution (CC BY) license (https:// creativecommons.org/licenses/by/ $4.0 /)$.

\begin{abstract}
Beyond being aging-related diseases, atherosclerosis and osteoporosis share common pathogenetic pathways implicated in bone and vascular mineralization. However, the contributory role of dyslipidemia in this interplay is less documented. The purpose of this narrative review is to provide epidemiological evidence regarding the prevalence of bone disease (osteoporosis, fracture risk) in patients with dyslipidemias and to discuss potential common pathophysiological mechanisms linking osteoporosis and atherosclerosis. The effect of hypolipidemic therapy on bone metabolism is also discussed. Despite the high data heterogeneity and the variable quality of studies, dyslipidemia, mainly elevated total and low-density lipoprotein cholesterol concentrations, is associated with low bone mass and increased fracture risk. This effect may be mediated directly by the increased oxidative stress and systemic inflammation associated with dyslipidemia, leading to increased osteoclastic activity and reduced bone formation. Moreover, factors such as estrogen, vitamin D and K deficiency, and increased concentrations of parathyroid hormone, homocysteine and lipid oxidation products, can also contribute. Regarding the effect of hypolipidemic medications on bone metabolism, statins may slightly increase BMD and reduce fracture risk, although the evidence is not robust, as it is for omega-3 fatty acids. No evidence exists for the effects of ezetimibe, fibrates, and niacin. In any case, more prospective studies are needed further to elucidate the association between lipids and bone strength.
\end{abstract}

Keywords: dyslipidemia; hypercholesterolemia; bone mineral density; osteoporosis; fractures; statins

\section{Introduction}

Dyslipidemias, which encompass a wide range of disorders in lipoprotein metabolism, constitute one of the leading causes of atherosclerotic cardiovascular disease (ASCVD) worldwide, mainly coronary heart disease (CHD) [1]. Osteoporosis is another common entity characterized by deterioration of bone microarchitecture, compromising bone strength and leading to increased risk of fractures [2]. Besides being age-dependent degenerative processes, atherosclerosis and osteoporosis share common underlying pathogenetic mechanisms involving bone and vascular mineralization [3]. Briefly, these include estrogen, vitamin D and K deficiency, increased concentrations of parathyroid hormone (PTH), homocysteine and lipid oxidation products, increased oxidative stress, and several other metabolic pathways that promote both the atherosclerotic process and bone loss. However, the role of dyslipidemias in skeletal health is less documented, with many studies yielding inconsistent results. 
The purpose of this narrative review is to provide epidemiological and pathophysiological evidence regarding the association between dyslipidemia and bone mass and fracture risk. The effect of available hypolipidemic agents on bone health is also discussed.

\section{The Association between Dyslipidemia and Bone Mineral Density or Fracture Risk}

\subsection{Bone Mineral Density}

In general, epidemiological data regarding the association between lipid profile and bone mineral density (BMD) are inconsistent. Although some studies have shown no association between dyslipidemia and BMD, others have reported either a negative or a positive effect for each lipid parameter [4-24]. A summary of the highly cited studies is presented in Table 1, illustrating their heterogeneity.

Table 1. Observational studies assessing the association between lipids and BMD in adults.

\begin{tabular}{|c|c|c|c|c|c|c|c|}
\hline \multirow{2}{*}{ Author/Year } & \multirow{2}{*}{$n$} & \multirow{2}{*}{ Country } & \multirow{2}{*}{ Gender } & \multirow{2}{*}{ Age (Years) } & \multicolumn{3}{|c|}{ Association with BMD } \\
\hline & & & & & TC/LDL-C & HDL-C & TG \\
\hline Yamaguchi, 2002 [4] & 214 & Japan & $\mathrm{F}$ & $47-86$ & - & + & no \\
\hline Poli, 2003 [5] & 1303 & Italy & $\mathrm{F}$ & $54.2 \pm 4.3$ & - & no & $\mathrm{N} / \mathrm{A}$ \\
\hline Tankó, 2003 [6] & 340 & Denmark & $\mathrm{F}$ & $50-75$ & - & $\mathrm{N} / \mathrm{A}$ & $\mathrm{N} / \mathrm{A}$ \\
\hline Adami, 2004 [7] & 982 & Italy & $\mathrm{M} / \mathrm{F}$ & $35-82$ & + & - & + \\
\hline Orozco, 2004 [8] & 52 & Spain & $\mathrm{F}$ & $55.2 \pm 3.8$ & - & - & - \\
\hline Samelson, 2004 [9] & 1162 & USA & $\mathrm{M} / \mathrm{F}$ & $32-61$ & - & - & $\mathrm{N} / \mathrm{A}$ \\
\hline Cui, 2005 [10] & 730 & Korea & $\mathrm{F}$ & $19-80$ & - & - & - \\
\hline Solomon, 2005 [11] & 13,592 & USA & $\mathrm{M} / \mathrm{F}$ & $>17$ & no & no & no \\
\hline Hsu, 2006 [12] & 13,970 & China & $\mathrm{M} / \mathrm{F}$ & $25-64$ & - & no & - \\
\hline Dennison, 2007 [13] & 513 & UK & $\mathrm{M} / \mathrm{F}$ & 64 & no & - & $\mathrm{N} / \mathrm{A}$ \\
\hline Tang, 2007 [14] & 368 & Taiwan & M & 78 & $\mathrm{~N} / \mathrm{A}$ & $\mathrm{N} / \mathrm{A}$ & + \\
\hline Makovey, 2009 [15] & 497 & Australia & $\mathrm{F}$ & $20-81$ & - & - & no \\
\hline Sivas, 2009 [16] & 107 & Turkey & $\mathrm{F}$ & $45-79$ & no & no & no \\
\hline Hernadez, 2010 [17] & 289 & Spain & M & $63.8 \pm 8.4$ & + & no & no \\
\hline Go, 2012 [18] & 958 & Korea & $\mathrm{F}$ & $58.6 \pm 5.8$ & - & + & $\mathrm{N} / \mathrm{A}$ \\
\hline Pliatsika, 2012 [19] & 591 & Greece & $\mathrm{F}$ & $53.0 \pm 5.65$ & no & + & no \\
\hline Kim, 2013 [20] & 6300 & Korea & $\mathrm{M}$ & $19-85$ & - & - & - \\
\hline Loke, 2018 [21] & 1162 & Taiwan & $\mathrm{M} / \mathrm{F}$ & $59.9 \pm 7.3$ & no & + & no \\
\hline Panahi, 2019 [22] & 2426 & Iran & $\mathrm{M} / \mathrm{F}$ & $69.1 \pm 6.3$ & - & - & + \\
\hline Chin, 2020 [23] & 400 & Malaysia & $\mathrm{M} / \mathrm{F}$ & $>40$ & $\mathrm{~N} / \mathrm{A}$ & no & no \\
\hline Zhang, 2020 [24] & 1116 & China & $\mathrm{F}$ & $58.2 \pm 13.9$ & no & no & no \\
\hline
\end{tabular}

Abbreviations: BMD—bone mineral density; F-females; HDL-C—high-density lipoprotein cholesterol; LDL-Clow-density lipoprotein cholesterol; $\mathrm{M}$-males; N/A—not available; no-no association; TC— total cholesterol; TG-triglycerides. Notes: (+) indicates positive association; (-) indicates negative association.

In brief, 712 women and 450 men (aged 32-61 years at baseline) in the seminal Framingham cohort were studied with serum lipid measurements every 2 years until 1988-1989, when bone densitometry was performed. No association was found between averaged total cholesterol (TC) and BMD at any of the assessed skeletal sites [total hip (TH), lumbar spine (LS), and distal radius] [9]. Survival bias is a possible reason for the absence of association since individuals with hyperlipidemia are at a higher risk of death compared to those with normal lipid profiles. This was also the case with another study, including 958 postmenopausal Korean women, which found no association between LS or femoral 
neck (FN) BMD with TC, low-density lipoprotein cholesterol (LDL-C), triglyceride (TG), or high-density lipoprotein cholesterol (HDL-C) concentrations, either at the beginning or at the end of follow-up (7.1 years). The study, however, could not account for the use of anti-osteoporotic medication, which may have influenced the results [18]. The absence of association between these lipid parameters with BMD was also supported by a Greek crosssectional study ( $n=591$ postmenopausal women) [19]. Interestingly, the authors found a negative association with LS BMD only for lipoprotein (a) (Lp(a)) in women $\geq 53$ years and for HDL-C for those $<53$ years [19]. As this study was based on a convenience sample of women attending a menopause clinic in a tertiary care hospital, selections biases cannot be excluded. A negative association between Lp(a) concentrations and LS or FN BMD was also shown in a cross-sectional study, including 52 overweight early postmenopausal women [8]. However, a post-hoc analysis from the Women's Health Initiative (WHI) study ( $n=9698$ postmenopausal women) showed no association between $\mathrm{Lp}(\mathrm{a})$ concentrations and hip BMD [25].

Another study investigated the association between lipid profile and BMD in two different cohorts, one from the general population ( $n=265$ males, 481 females) and one from patients attending an osteoporosis clinic ( $n=236$ pre- and postmenopausal women) [7]. In both groups, TH BMD was positively associated with LDL-C $(p<0.05)$ and TG $(p<0.05)$ and negatively with HDL-C concentrations $(p<0.05)$ in both genders, even after adjustment for body weight, height, and fat mass. Total body and LS BMD were also positively associated with LDL-C and TG and negatively with HDL-C concentrations in the general population and the clinic cohort, respectively [7]. The positive association of TH BMD with TC/LDL-C and the inverse association with HDL-C was replicated in a large US cohort $(n=13,592$ participants of the National Health and Nutritional Examination Survey (NHANES) III). Nevertheless, after correction for potential confounders, such as age, sex, body mass index (BMI), and statin use, the association between lipid profile and BMD lost significance [11].

In contrast, another cross-sectional study $(n=1303$ postmenopausal women who attended a menopause clinic) showed a higher prevalence of low LS BMD in those with high LDL-C concentrations ( $>160 \mathrm{mg} / \mathrm{dL}$ ) compared with those with LDL-C $<160 \mathrm{mg} / \mathrm{dL}$ ( $47.9 \%$ vs. $21.2 \%$, respectively) [5]. A Japanese study in postmenopausal women referred to a tertiary care clinic for the evaluation of osteoporosis also showed an inverse association between LDL-C and forearm BMD, including 214 postmenopausal women. LS BMD was marginally not associated with LDL-C $(p=0.051)$. On the other hand, HDL-C concentrations were positively correlated with BMD values in these sites [4].

Aiming to overcome these discrepancies, some meta-analyses were conducted. One meta-analysis that included ten studies [26] compared the lipid profile between postmenopausal women with osteoporosis and normal BMD. HDL-C and TC concentrations were higher in the osteoporosis compared with the normal BMD group [HDL-C: mean difference (MD) 2.63, 95\% confidence interval (CI) 0.43-4.84; TC: MD 14.82, 95\% CI 2.84-26.80]. LDL-C concentrations also tended to be higher in the osteoporosis group (LDL-C: MD 9.67, $95 \%$ CI from -0.10 to 19.44$)$. No difference in TG concentrations between groups was observed.

Another recent meta-analysis [27] included data from 12 case-control studies in patients with osteopenia or osteoporosis $(n=12,395)$. It investigated the difference in lipid profile in comparison with individuals with normal BMD. Regarding TC, there was no difference between patients with low bone mass (osteopenia or osteoporosis) and controls, irrespective of gender or hypolipidemic medication. This was also the case regarding LDL-C and TG concentrations. LDL-C concentrations were higher only in the osteoporosis subgroup, which was not prescribed any lipid-lowering medication, compared with controls [(mean difference (MD) $0.16 \mathrm{mmol} / \mathrm{L}$, confidence interval (CI) 0.02-0.31]. Moreover, TG concentrations were slightly higher in patients with osteopenia compared with controls only in the subgroup prescribed hypolipidemic treatment (MD $0.07 \mathrm{mmol} / \mathrm{L}$, 95\% CI 0.03-0.12). Concerning HDL-C concentrations, these were higher in patients with 
osteoporosis compared with those with normal BMD (MD $0.05 \mathrm{mmol} / \mathrm{L}, 95 \%$ CI 0.03-0.07), whereas there was no difference between osteopenia and control groups in this regard.

Few studies exist in children and adolescents concerning the association between lipid profile and BMD, yielding inconsistent results. In a cross-sectional study from China ( $n=14,303 ; 49.9 \%$ boys; mean age $11.4 \pm 3.3$ years), an inverse association was observed in both sexes between serum TG concentrations and calcaneus BMD [28]. Similar results were shown in a cross-sectional study from Spain ( $n=188$ overweight/obese children; mean age $10.4 \pm 1.2$ years), in which metabolically unhealthy children with metabolic syndrome (including high TG and low HDL-C concentrations) presented lower areal BMD compared with metabolically healthy ones [29]. In contrast, a cross-sectional study from the UK ( $n=2305 ; 47.7 \%$ males; mean age 15.5 years) showed a positive association between serum TG and total body BMD, bone mineral content, and bone area. HDL-C was inversely associated with these parameters [30]. Moreover, in a small, cross-sectional study ( $n=47$ Caucasian male adolescents; mean age 16.9 years), a positive association was observed between serum Lp(a) concentrations and femoral neck BMD [31]. However, in a cross-sectional study ( $n=306$ girls; mean age $10.8 \pm 1.1$ years), there was no association between lipid profile (TG, HDL-C, LDL-C) and total or areal BMD [32].

\subsection{Dyslipidemia and Fractures}

In general, little data exist concerning the association between dyslipidemia and fractures. According to a recent meta-analysis, which included ten studies (six prospective, three cross-sectional, and one case-control; $3-20$ years of follow-up; $n=60,484$ individuals; mean age $>25$ years), a $50 \mathrm{mg} / \mathrm{dL}$ increase in TC concentrations was associated with $15 \%$ higher risk of fractures (combined effect size 1.15, 95\% CI 1.02-1.30). Concerning HDL-C, although there was no association with fractures, subgroup analysis from prospective studies showed an $18 \%$ lower risk of fractures in those with HDL-C $<40 \mathrm{mg} / \mathrm{dL}$ compared with individuals with HDL-C $>40 \mathrm{mg} / \mathrm{dL}$ (combined effect size: $0.82,95 \%$ CI $0.71-0.96$ ). Finally, no association between either TG or LDL concentrations and fracture risk was documented [33]. Similarly, no association exists between Lp(a) concentrations and fracture risk [25].

\subsection{Critical Review of Available Data}

The abovementioned data point towards a positive association between dyslipidemia (especially high TC and LDL-C concentrations) and low bone mass or fractures, although firm conclusions cannot be drawn. Most of these studies were cross-sectional in design or used a convenience sample. Furthermore, many confounders, such as dietary habits of calcium intake, alcohol or caffeine consumption, smoking, socioeconomic status, ethnicity, gender, exercise and physical activity, or comorbidities such as diabetes, which intervene with the association between lipid profile and bone mass, should be acknowledged. Another shortcoming of these studies is excluding patients with ASCVD prescribed lipid-lowering medication or at high risk of fracture prescribed anti-osteoporotic medication.

\section{Pathogenetic Mechanisms Linking Dyslipidemia and Atherosclerosis with Impaired Bone Metabolism}

\subsection{Direct Effect of Dyslipidemia on Bones}

Several, though not all, lines of evidence have shown an inverse association of BMD with TC and LDL-C [34]. It has been suggested that increased cholesterol inhibits osteoblast differentiation, preventing bone formation [35]. Enhanced osteoclastogenesis may also be involved [35]. A differential effect of serum cholesterol on BMD at various skeletal sites has been suggested [34], explaining the inconsistency among studies. Furthermore, low HDL-C concentrations have been associated with the development of an inflammatory microenvironment and increased bone marrow adiposity, which restrains the differentiation and function of osteoblasts, leading to reduced bone mass [36]. 
Bones and vascular tissue share similar pathological features. As with atherosclerosis, increased lipids accumulate beneath the vascular intima and perivascular space in bones [37]. Furthermore, inflammatory bioactive lipids, which promote atherosclerosis, also induce bone loss [37], whereas oxidized LDL-C appears to play a major role in bone loss [38]. Lipid oxidation products, such as minimally oxidized LDL-C, promote arterial calcification, possibly by activating osteoblasts in the arterial pool, while their accumulation in the subendothelial space of skeletal bone arteries inhibits bone formation [39]. Dyslipidemias are also associated with impaired nitric oxide (NO) and enhanced endothelin production, leading to endothelial cell dysfunction and increased thrombotic risk [40]. Additionally, isoprostanes, present in atherosclerotic plaques, enhance vasoconstriction and endothelin-1 release in endothelium and modulate platelet aggregation [41]. Isoprostanes also inhibit osteoblastic differentiation of pre-osteoblasts and enhance osteoclastic differentiation and activity [41]. Overall, lipids appear to be involved in bone remodeling and atherosclerosis progression in opposite directions, explaining the simultaneous existence of osteoporosis and atherosclerosis in people with dyslipidemia [42].

Other mechanisms involve fat accumulation in the femoral head, which increases bone marrow microcirculation pressure and reduces bone vascularization, resulting in ischemia and hypoxia [43]. Moreover, increased blood viscosity also compromises bones' blood supply [43]. All these phenomena may lead to bone necrosis and fractures [43]. A summary of the direct and indirect mechanisms linking dyslipidemia with bone loss is provided in Table 2.

Table 2. Pathogenetic mechanisms linking dyslipidemia and atherosclerosis with impaired bone metabolism.

\begin{tabular}{|c|c|}
\hline Direct effects & $\begin{array}{ll}\text { - } & \uparrow \text { Cholesterol } \rightarrow \downarrow \text { osteoblast differentiation, } \uparrow \text { osteoclastogenesis } \\
\text { - } & \downarrow \text { HDL-C } \rightarrow \downarrow \text { osteoblast differentiation and function } \\
\text { - } & \text { Oxidized LDL-C } \rightarrow \uparrow \text { bone loss } \\
\text { - } & \uparrow \text { Fat accumulation in the femoral head } \rightarrow \text { ischemia and hypoxia } \\
\text { - } & \uparrow \text { Blood viscosity, which compromises bones' blood supply }\end{array}$ \\
\hline Estrogens & $\begin{array}{l}\text { - } \quad \downarrow \text { Estrogens } \rightarrow \downarrow \text { osteoblast differentiation, } \uparrow \text { osteoclastogenesis, } \downarrow \text { bone mass, } \\
\text { atherogenic dyslipidemia } \rightarrow \uparrow \text { atherosclerosis and fracture risk } \\
\text { Inverse association between estrogen and serum homocysteine and oxidized } \\
\text { LDL-C concentrations }\end{array}$ \\
\hline Vitamin D, PTH & $\begin{array}{l}\text { - Low vitamin D status } \rightarrow \text { secondary hyperparathyroidism } \rightarrow \downarrow \text { bone mass, } \\
\text { dyslipidemia, } \uparrow \text { cardiovascular risk }\end{array}$ \\
\hline Inflammation & $\begin{array}{l}\text { Dyslipidemia } \rightarrow \text { systemic inflammation ( } \uparrow \text { TNF- } \alpha \text {, IL-1, IL-6, IL-17, C-reactive } \\
\text { protein) } \rightarrow \uparrow \text { osteoclastogenesis, osteoporosis }\end{array}$ \\
\hline Gla proteins (MGP and osteocalcin) & - Involvement in mineralization of bones and arteries \\
\hline Vitamin $\mathrm{K}$ & $\begin{array}{l}\text { - } \quad \text { Essential co-factor for the formation of Gla proteins } \\
\text { - } \quad \text { Protects against osteocalcin-induced calcification }\end{array}$ \\
\hline Osteopontin & $\begin{array}{ll}\text { - } & \uparrow \text { Osteoclast activity, bone resorption } \\
\text { - } & \uparrow \text { Systemic inflammation, atherosclerosis, and plaque calcification } \\
\end{array}$ \\
\hline BMPs & $\begin{array}{l}\text { - Involved in osteoblast differentiation and proliferation } \\
\text { - } \quad \text { Vascular calcification promotion }\end{array}$ \\
\hline Homocysteine & $\begin{array}{ll}\text { - } & \uparrow \text { Osteoclastogenesis, osteoclast activity, bone resorption } \\
\text { - } & \downarrow \text { Blood supply and impairment of bone biomechanical properties } \\
\text { - } & \text { Association with premature atherosclerosis and thromboembolism }\end{array}$ \\
\hline
\end{tabular}


Table 2. Cont.

\begin{tabular}{lll}
\hline Nitric oxide & - $\begin{array}{l}\uparrow \text { Vascular smooth muscle relaxation, } \downarrow \text { LDL-C oxidation, platelet aggregation, and } \\
\text { adhesion } \\
\uparrow \text { Bone formation and fracture healing }\end{array}$ \\
\hline RANK/RANKL/OPG axis & - $\begin{array}{l}\uparrow \text { Osteoclastogenesis, osteoclast activity, bone resorption } \\
\text { Wnt pathway }\end{array}$ & - Association with arterial and valve calcification
\end{tabular}

Abbreviations: BMPs—-bone morphogenetic proteins; Gla—carboxyglutamic acid; HDL-C—high-density lipoprotein cholesterol; IL-interleukin; LDL-C-low-density lipoprotein cholesterol; MGP-matrix Gla protein, PTH - parathyroid hormone; RANK/RANKL/OPG—receptor activator of nuclear factor kappa-B//RANK ligand/osteoprotegerin; TNF- $\alpha$-tumor necrosis factor- $\alpha$; Wnt-Wingless-related integration site; $\uparrow:$ increased; $\downarrow$ decreased.

\subsection{Indirect Mechanisms}

\subsubsection{Estrogens}

Bone and coronary arteries are target organs for estrogens. Indeed, estrogen receptors have been detected on osteoblasts, osteoclasts, and coronary artery smooth muscle cells [44]. Estrogen loss during the transition to menopause leads both to bone loss [45] and atherogenic dyslipidemia [46,47]. Reduced estrogen concentrations have also been associated with increased PTH secretion [48] and, subsequently, accelerated bone loss and soft tissue calcium deposition, including vascular and myocardial calcification [49]. Moreover, an inverse association between estrogen and serum homocysteine concentrations, as well as oxidized LDL-C, has been reported [3], which may partly explain the increased risk for both osteoporosis and atherosclerosis in menopause.

\subsubsection{Vitamin D and PTH}

Vitamin D and PTH are associated with the regulation of phosphorus metabolism, and dysregulated phosphorus metabolism is associated with bone mineral disorders and vascular calcification [50]. Vitamin D deficiency leads to decreased calcium absorption from the intestine and calcium release from bones to maintain normal serum calcium concentrations [51]. Moreover, low vitamin D status increases fracture risk via secondary hyperparathyroidism, leading to bone demineralization and the development of osteomalacia and osteoporosis [51]. On the other hand, vitamin D receptors (VDR) are present in endothelial and smooth muscle cells of the arterial wall [3,52]. Some, but not all, studies suggest that polymorphisms of VDR may be involved in the mutual risk between osteoporosis and atherosclerosis [3,52]. Moreover, increased PTH concentrations are associated with an increased risk of ASCVD [53].

\subsubsection{Systemic Inflammation}

Inflammation is an important component in the pathogenesis of atherosclerosis and osteoporosis, and inflammatory rheumatic diseases have been associated with secondary atherosclerosis and increased bone loss [54]. Several inflammatory mediators are involved in both clinical entities. Furthermore, high concentrations of some inflammatory mediators [e.g., tumor necrosis factor $\alpha$ (TNF- $\alpha$ ), interleukin (IL)-1, IL-6, IL-17, and C-reactive protein] have been associated with increased risk of myocardial infarction and non-traumatic fragility fractures [53].

\subsubsection{Carboxyglutamic Acid (Gla) Proteins}

Gla proteins, including matrix Gla protein (MGP) and osteocalcin, encompass a part of a family of mineral-binding proteins. Gla residues bind and incorporate calcium into hydroxyapatite crystals [55]. MGP is a secretory protein with widespread tissue expression, including bones and vascular walls, inhibiting the osteoid formation and mineralization [56,57]. Osteocalcin, an abundant protein in bones, also inhibits calcification. Data from animal studies suggest that depletion or dysregulation of these proteins leads to 
abnormal mineralization of bones and arteries [56]. Regarding humans, MGP is integrally expressed in the normal aorta, while it is up-regulated in atherosclerotic plaques [58], probably to limit vascular osteogenesis. Osteocalcin resembles MGP expression in normal and atherosclerotic human vessels [59]. Indeed, increased serum osteocalcin concentrations have been observed in women with both atherosclerosis and osteoporosis [60,61].

\subsubsection{Vitamin K}

Vitamin $\mathrm{K}$ is an essential co-factor for the formation of Gla proteins. Accordingly, reduced availability of vitamin $\mathrm{K}$ has been associated with functionally defective Gla proteins, which cannot properly form the matrix in which calcium and phosphorus bind together to make solid, well-mineralized bone; thus, low BMD ensues [62]. On the other hand, impaired vitamin $\mathrm{K}$ status has been associated with the presence of atherosclerotic calcification [3]. A possible underlying mechanism is that, by increasing MGP in the arterial wall, vitamin K protects against the calcification induced by osteocalcin [62].

\subsubsection{Osteopontin}

Osteopontin (OPN) is an extracellular, non-collagenous bone matrix glycoprotein, which binds to integrins, especially the $\alpha v \beta 3$ one. Integrins are transmembrane proteins that facilitate cell-cell and cell-extracellular matrix adhesion [63]. In bone, upon OPN binding, integrin $\alpha v \beta 3$ activates signal transduction pathways that mediate osteoclast attachment to resorption sites [55,64], subsequently promoting bone resorption [64-66]. Apart from bones, OPN appears to be involved in vascular inflammation and atherosclerosis [67]. Several lines of evidence suggest that OPN promotes atherosclerotic plaque formation, leading to artery calcification [68-70]. In patients with CHD, OPN was found to be localized in calcified atherosclerotic lesions [59] and calcified cardiac valves [71]. Several possible underlying mechanisms regarding the association of OPN expression with increased atherosclerotic risk have been proposed, such as enhanced endothelial cell migration via $\alpha \mathrm{v} \beta 3$ ligand, increased macrophage activation, and cytokine release by OPN $[72,73]$.

\subsubsection{Bone Morphogenetic Proteins}

Bone morphogenetic proteins (BMPs) belong to the transforming growth factor $\beta$ (TGF- $\beta$ ) superfamily. TGF- $\beta$ exerts a fundamental role in regulating osteoblast differentiation and proliferation [74,75]. Among BMPs, BMP-2 and BMP-7 promote collagen synthesis and are involved in bone and cartilage formation [76]. Besides its role in bone homeostasis, BMP signaling has also been well described in endothelial cells [77]. Furthermore, megakaryocytes and platelets also contain BMP-2 and BMP-4 [78], the latter being a mediator of vascular inflammation in early atherosclerosis and restenosis [79].

Considering that BMPs induce bone formation and that BMP-2 is expressed by vascular endothelial and smooth muscle cells, it may be assumed that the vascular expression of BMPs could favor calcification. Indeed, increased BMP-2 and Cbfa-1 have been demonstrated in human atherosclerotic lesions, whereas this does not occur in normal arteries [80]. Furthermore, BMP-2 expression in the arterial wall is regulated by proinflammatory stimuli, such as TNF- $\alpha$ and oxidized lipids, hyperglycemia, and maybe a feature of atherosclerotic calcification [81].

\subsubsection{Homocysteine}

Homocysteine is involved in bone metabolism via several mechanisms. Overall, it fosters osteoclastogenesis and increases osteoclast activity, subsequently enhancing bone resorption, while it decreases osteoblast activity and delays the synthesis of complex crosslinks in collagen [82]. Of note, hyperhomocysteinemia appears to be a marker for increased risk of osteoporosis and osteoporotic fractures, as it reduces blood supply in the bone and may influence the biomechanical properties of bones [83]. However, data regarding the link between homocysteine and osteoporosis are inconsistent [84-86]. On the other 
hand, hyperhomocysteinemia has also been associated with premature atherosclerosis and thromboembolism. Several underlying mechanisms have been proposed, such as endothelial dysfunction, diminished NO bioavailability, lipid peroxidation, smooth muscle cell proliferation, and increased platelet aggregation $[87,88]$. Of note, dyslipidemia (mainly hypertriglyceridemia and low HDL-C concentrations) is positively associated with serum homocysteine concentrations [89].

\subsubsection{Nitric Oxide}

NO has atheroprotective properties. Briefly, endothelial NO promotes vascular smooth muscle relaxation and inhibits platelet aggregation and adhesion, as well as LDL-C oxidation [90-92]. NO is also produced in bone cells by all three NO synthase (NOS) isoforms, i.e., endothelial, neural, and inducible NOS [93]. Concerning bone metabolism, low physiological NO concentrations stimulate bone formation and fracture healing, whereas pathologically, high NO concentrations inhibit these processes [94]. Consistently, animal studies suggest that the biological response to NO is dose-dependent in bone and vascular tissue, with NOS accentuating bone loss and NOS deficiency accelerating atherosclerosis and osteoporosis [42].

\subsubsection{RANK/RANKL/OPG System}

The receptor activator of nuclear factor kappa-B (RANK)/RANK ligand (RANKL)/ osteoprotegerin (OPG) system plays a major role in maintaining the coupling between bone resorption by osteoclasts and bone formation by osteoblasts [95]. RANKL is released by osteoblast lineage cells and binds to RANK, leading to the differentiation of osteoclast precursor cells into mature osteoclasts [96]. OPG is a soluble glycoprotein, largely expressed in osteoblast lineage cells and various other cell types, including vascular endothelial cells [97]. OPG, as a decoy receptor for RANKL, inhibits RANK-RANKL interactions and subsequently osteoclastogenesis and bone resorption [98]. On the other hand, the upregulation of the RANK/RANKL/OPG axis has been associated with arterial and valve calcification [99].

\subsubsection{Wnt Pathway}

The Wingless-related integration site (Wnt) pathway, which comprises a large family of 19 secreted signaling glycoproteins and 10 frizzled receptors [100], is involved in regulating osteoblastogenesis and bone formation. These glycoproteins bind to receptor complexes, such as LDL receptor-related proteins (LRP)-5 and LRP-6 [101], and stimulate gene expression associated with bone development [102]. Accumulating evidence suggests that Wnt signaling improves intracellular cholesterol trafficking through mechanisms other than the classical LDL receptor pathway. Of note, Wnts have been demonstrated to protect against atherosclerosis and coronary artery occlusion [103]. Furthermore, Wnt ligands appear to regulate the pathologic calcification in the vasculature and the osteoblastic trans-differentiation of smooth vascular cells in vitro [104]. Wnt signaling antagonism by oxidative stress may be one of the underlying mechanisms associated both with osteoporosis and atherosclerosis, as well as impaired glucose and lipid metabolism [105].

Sclerostin, an inhibitor of Wnt-mediated osteoblast activation and bone formation, is also involved in bone resorption and subsequent BMD reduction [106] and is associated with early atherosclerosis [107].

\subsubsection{Cbfa1 and Runx-2 Transcription Factors}

The transcription factors core-binding factor alpha 1 (Cbfa1) and runt-related transcriptional factor-2 (Runx-2) promote osteoblastic differentiation at the early stage but inhibit it at the late stage $[3,108]$. These factors enhance the expression of bone matrix protein genes and the mineralization in immature mesenchymal and osteoblastic cells in vitro [3,108]. Moreover, Runx-2 expression has been identified in atherosclerotic human vascular tissue 
specimens. Specifically, oxidative stress likely induces vascular smooth cell calcification by modulating Runx-2 [109].

\section{The Effect of Hypolipidemic Medications on Bone Metabolism}

\subsection{Statins}

The 3-hydroxy-3-methylglutarylo-CoA (HMG-CoA) reductase inhibitors (statins) are the most widely prescribed lipid-lowering agents, constituting the mainstay of treatment both in adults and children with hypercholesterolemia [110,111]. Preclinical and clinical data suggest a potential beneficial effect on bone metabolism. In particular, statins may inhibit osteoclastic activity since HMG-CoA blockade reduces the production of downstream products in the mevalonate pathway, such as farnesyl pyrophosphate (FPP) and geranylgeranyl pyrophosphate (GGPP) [112]. The same pathway is also shared by nitrogencontaining bisphosphonates, thus preventing the prenylation of guanosine triphosphate (GTP)-ases, such as Ras, Rho, and Rac, which are essential for the survival and function of osteoclasts [113]. Another mechanism could be the inhibition of RANKL, which is essential for osteoclast differentiation by averting the production of reactive oxygen species [114]. Statins may also increase 25-hydroxy-vitamin D concentrations [52].

Statins also exert osteoanabolic properties, inhibiting osteoblast apoptosis and fostering osteoblast activity. This mechanism is mediated through increased expression of the $B M P-2$ gene, which promotes osteoblast differentiation [115]. The latter is also induced by the depletion of FPP and GGPP, as mentioned above [116]. Statins may also promote embryonic stem cell differentiation towards the osteogenic lineage, through activation of increased mRNA expression of runt-related gene 2 (Runx2), osterix (OSX), and osteocalcin $(\mathrm{OCN})$, as osteogenic transcription factors [117].

However, data in humans regarding the effect of statins on bone mass and, more importantly, fracture risk are not robust and consistent. A meta-analysis of randomized controlled trials (RCTs), published in 2016, including seven studies involving a total of 27,900 subjects, showed an increase in BMD by $0.03 \mathrm{~g} / \mathrm{cm}^{2}$ (95\% CI 0.006-0.053; $\mathrm{I}^{2}$ 99.2\%; $p<0.001$ ) with statins. Concerning the skeletal site, four studies assessed BMD in LS, one in the distal radius and two in any of multiple skeletal sites. Regarding fracture risk, no association with statin use was observed [pooled hazard ratio (HR) 1.00, 95\% CI $\left.0.87-1.15 ; \mathrm{I}^{2} 0 ; p=0.396\right]$. These findings remained consistent and significant in sensitivity analysis [118].

These results were replicated by another meta-analysis published in 2017, including 33 studies (23 observational and ten RCTs) with 314,473 patients on statin therapy and 1,349,192 controls [119]. In particular, statins increased LS BMD (standardized MD (SMD) $0.20,95 \%$ CI 0.07-0.32; $p=0.002 ; \mathrm{I}^{2} 43 \%$ ), as well as TH BMD (SMD 0.18, 95\% CI 0.00-0.36; $\left.p<0.05 ; \mathrm{I}^{2} 62 \%\right)$. In subgroup analyses, these associations remained significant only for data derived from cohort studies but not for RCTs. Notably, there was no gender difference regarding $\mathrm{TH}$, but LS BMD increased only in males. Concerning FN BMD, no association with statin use was found. Regarding fracture risk, statins decreased the risk of overall (odds ratio (OR) $0.81,95 \%$ CI $0.73-0.89 ; p<0.0001 ; \mathrm{I}^{2} 87.5 \%$ ) and hip fractures (OR $0.75,95 \%$ CI $0.60-0.92 ; p=0.007 ; \mathrm{I}^{2} 77.2 \%$ ), however, with no effect on vertebral and upper extremity fractures (data from 16 cohort and case-control studies). The authors also assessed the effect of statins on markers of bone turnover, showing a positive effect on osteocalcin concentrations (SMD 0.21,95\% CI 0.00-0.42; $p=0.04 ; \mathrm{I}^{2}=0 \%$ ), but no effect on bone-specific alkaline phosphatase (bALP) and serum C-terminal peptide of type I collagen (CTX) concentrations [119].

Interestingly, a recent Mendelian randomization (MR) study showed that the effect of statins on BMD was dependent on the degree of their LDL-C-lowering action. MR explained this by utilizing 400 single nucleotide polymorphisms, which provided evidence for a causal effect of LDL-C on BMD [120].

Another recent meta-analysis assessed the effect of statin use exclusively on fracture risk in older adults [121]. The authors included 21 observational studies and two 
RCTs ( $n=1,783,123$ participants). Data from the observational studies showed an overall decreased fracture risk with statin use [pooled relative risk (RR) 0.80, 95\% CI 0.72-0.88; $\left.\mathrm{I}^{2} 93.1 \%\right]$. In subgroup analysis, this association was more evident in men (RR 0.75 , 95\% CI 0.59-0.95) than in women (RR 0.87,95\% CI 0.76-0.99) and only for hip (RR 0.73, 95\% CI 0.64-0.82) and low extremity fractures (RR $0.69,95 \%$ CI 0.54-0.88). In terms of statin type, only atorvastatin was associated with a reduction in fracture risk (RR 0.77 , 95\% CI 0.71-0.84) compared to other statins. Interestingly, this beneficial effect was shown only for a short duration of statin use ( $<1$ year) (RR $0.66,95 \%$ CI $0.47-0.93$ ), but not for a higher duration (1-3 or $>3$ years). Of note, it must be emphasized that the evidence for an anti-fracture efficacy for statins was based only on data derived from observational studies. In the two RCTs, there was no evidence for reducing fracture risk with statin use (RR 1.00, $95 \%$ CI $0.87-1.15 ; I^{2}$ 0\%) [121].

\subsection{Ezetimibe}

Ezetimibe acts by blocking the cholesterol transport protein Nieman-Pick C1-like 1 (NPC1L1) protein, inhibiting the intestinal absorption of cholesterol. This increases the expression of the LDL-C receptor in hepatocytes, resulting in reductions in serum LDL-C concentrations by $20 \%$ [122]. However, due to the concomitant upregulation of cholesterol biosynthesis, mevalonate concentrations may increase. Scarce data exist concerning its effect on bone metabolism. In particular, the inhibition of NPC1L1 protein has raised the hypothesis of reduced vitamin D absorption since NPC1L1 is an important sterol transporter [123]. Although experimental data have shown a decrease in $25(\mathrm{OH}) \mathrm{D}$ concentrations [124], this has not been shown in human studies [125]. Moreover, in an open-label study ( $n=54$ patients with hypercholesterolemia), no effect in LS and TH BMD, as well as in bone turnover markers (bALP and CTX), was observed with ezetimibe [126].

\subsection{PCSK-9 Inhibitors}

No data concerning the effect of proprotein convertase subtilisin/kexin type 9 (PCSK-9) inhibitors on bone metabolism are currently available.

\subsection{Fibrates}

Fibrates are proliferator-activated receptor (PPAR)- $\alpha$ agonists, mostly used in patients with hypertriglyceridemia. They are moderately effective agents in reducing plasma TG (by $50 \%)$ and, to a lesser extent, LDL-C $(\leq 20 \%)$, as well as in increasing HDL-C concentrations $(\geq 20 \%)$ [127].

Concerning bone metabolism, preclinical data have demonstrated that fibrates and, in particular, fenofibrate promote $B M P-2$ gene expression, thus, stimulating the osteoblast differentiation [128]. Fenofibrate has been shown to maintain FN and whole-body BMD and bone architecture in ovariectomized rats, compared with pioglitazone [129]. However, others have shown a detrimental effect on bone quality in mice with diabetes mellitus, through decreased collagen I and osteocalcin secretion, due to down-regulation of Runx2 gene expression [130].

The evidence for any clinical effect of fibrates on bone health is generally poor. In a case-control study, including 124,655 fracture cases and 373,962 age- and gender-matched controls, an increased risk for non-statin lipid-lowering agents (mainly cholestyramine and fibrates) was demonstrated. In contrast to statins, the use of these non-statin drugs was associated with an increased crude risk of vertebral (OR 2.25; 95\% CI 1.22-4.16) and total fractures (OR 1.14, 95\% CI 1.00-1.30). However, this association lost significance after adjustment for potential confounders [131].

\subsection{Omega-3 Fatty Acids}

The omega-3 fatty acids (FA) and, in particular, docosahexaenoic (DHA) and eicosapentaenoic acid (EPA) are essential polyunsaturated FA, derived mainly from fish oil [127]. They are moderately efficacious in lowering serum TG concentrations in a dose-dependent 
manner, with usual doses of 2-4 g/day, although their effect on other lipoproteins is trivial [127]. A cardiovascular benefit has been shown in patients at very high CVD risk with high doses (2 g of EPA twice a day) [127].

Preclinical data suggest a protective effect of omega-3 FA on bone metabolism since a high dietary intake increases the rate of bone formation [132]. They also reduce osteoclastic activity and the ensuing bone resorption by $80 \%$, as shown in rats fed with a purified diet rich in omega-3 FA [133]. Furthermore, fat- 1 transgenic mice, which can convert omega- 6 to omega-3 FAs, demonstrate significant acceleration in callus formation and fracture healing compared with controls [134].

Epidemiological data in humans regarding the effect of omega-3 FA on musculoskeletal outcomes have provided inconsistent results. A meta-analysis of observational studies (including seven prospective and three case-control studies; $n=292,657$ participants) showed an inverse association between fish consumption and the risk of hip fractures (pooled effect size $0.88,95 \%$ CI 0.79-0.98, for the highest compared with the lowest quartile) [33]. However, in subgroup analysis, this association was evident only in case-control studies and in prospective studies with a sample size of $\geq 10,000$ participants. Moreover, an inverse association between omega-3 FA intake and the risk of hip fracture was observed (pooled effect size: $0.89,95 \%$ CI 0.80-0.99) [33].

In a systematic review and meta-analysis of ten RCTs published in 2012, a favorable effect of omega-3 FA on BMD or bone turnover markers was demonstrated in four studies, but only when co-supplemented with calcium, whereas three studies showed no effect. No data on fractures were available [135]. Another meta-analysis of 28 RCTs (23 studies on omega-3 FA; 0.4-5.8 g/day of EPA and/or DHA, 3.5-9.1 g/day of alpha-linoleic acid) showed no effect on LS (mean difference $0.03 \mathrm{~g} / \mathrm{cm}^{2}, 95 \%$ CI from -0.02 to 0.07 ) or FN BMD (mean difference $0.04 \mathrm{~g} / \mathrm{cm}^{2}, 95 \% \mathrm{CI}$ from -0.00 to 0.07 ) (low or very low quality of evidence, respectively) [136]. A high omega-3 dose induced a slight increase in osteocalcin concentrations, but no effect was observed on other bone formation or bone resorption markers [136]. No data on fractures were available from both meta-analyses $[135,136]$.

\subsection{Niacin}

Niacin (nicotinic acid) is effective in reducing serum TG concentrations by inhibiting the secretion of very-low-density lipoprotein (VLDL) particles from the liver [127]. It also increases HDL-C concentrations due to increased production of apolipoprotein-A1 in the liver [127]. However, its cardiovascular benefit has not been proven, and therefore, it is currently not available in Europe [127].

Very little data exist concerning the effect of niacin on skeletal outcomes. A prospective community-based study, the Cardiovascular Health Study (CHS), including 5187 men and women $\geq 65$ years, showed a U-shaped association between dietary niacin consumption with hip fracture risk. In particular, both lowest (3.6-21.8 mg/day) and highest (41.0-102.4 mg/day) consumption were associated with increased risk of hip fracture [HR 1.31 (95\% CI 1.04-1.66) and 1.53 (95\% CI 1.20-1.95), respectively] compared with daily intakes of 21.9-40.9 mg. A trend for an inverse association with hip BMD was also found $(p=0.06)$ [137]. However, the latter was not confirmed in another study in 243 pre- and 137 postmenopausal Japanese women, showing a positive association between dietary niacin intake and calcaneus BMD [138].

\subsection{Bile Acid Sequestrants}

Very few data exist with regard to the effect of bile acid sequestrants, such as cholestyramine, colestipol, or colesevelam, on bone metabolism. In a prospective study, cholestyramine $24 \mathrm{~g}$ /day, administered either as monotherapy or in combination with pravastatin, had no effect on PTH, 25-hydroxy-vitamin D, and 1,25-dihydroxy-vitamin D concentrations [139]. 


\section{Conclusions}

Despite the high heterogeneity and the variable quality of evidence, dyslipidemia, mainly high TC and LDL-C and, to a lesser extent, TG concentrations, seems to be associated with low bone mass and increased fracture risk. This detrimental effect may be mediated directly through the increased oxidative stress and systemic inflammation that dyslipidemia is associated with, leading to increased osteoclastic activity and reduced bone formation, or through the atherosclerotic process, which affects bone's vascularization. Other mechanisms, such as low estrogen, vitamin D and K status, and increased concentrations of $\mathrm{PTH}$, homocysteine, and lipid oxidation products, may also contribute to this interplay. Regarding the effect of lipid-lowering therapy on bone metabolism, statins may slightly increase BMD, with a tendency to reduce fracture risk as shown in case-control and cohort studies, although available RCTs have not shown any effect of statins on fracture risk. This is also the case for omega-3 FA, whereas inconsistent or insufficient evidence exists for other commonly used lipid-lowering medications, such as ezetimibe, fibrates, and niacin. There is an exigent need for prospective, well-designed studies in males and females to elaborate on the putative association between lipids and bone strength.

Author Contributions: P.A. designed the research, analyzed the extractable data and wrote the first draft of the paper. M.F. and S.L. searched the literature and provided critical scientific input. I.L. and D.G.G. provided critical scientific input and had the primary responsibility for the paper's final content. All authors have read and agreed to the published version of the manuscript.

Funding: This research received no external funding.

Institutional Review Board Statement: Not-applicable.

Informed Consent Statement: Not applicable.

Data Availability Statement: Not applicable.

Conflicts of Interest: The authors have no conflict of interest to disclose.

\section{References}

1. Hajar, R. Risk Factors for Coronary Artery Disease: Historical Perspectives. Heart Views 2017, 18, 109-114. [CrossRef] [PubMed]

2. NIH Consensus Development Panel on Osteoporosis Prevention, Diagnosis, and Therapy. Osteoporosis prevention, diagnosis, and therapy. JAMA 2001, 285, 785-795. [CrossRef] [PubMed]

3. Anagnostis, P.; Karagiannis, A.; Kakafika, A.I.; Tziomalos, K.; Athyros, V.G.; Mikhailidis, D.P. Atherosclerosis and osteoporosis: Age-dependent degenerative processes or related entities? Osteoporos. Int. 2009, 20, 197-207. [CrossRef]

4. Yamaguchi, T.; Sugimoto, T.; Yano, S.; Yamauchi, M.; Sowa, H.; Chen, Q.; Chihara, K. Plasma lipids and osteoporosis in postmenopausal women. Endocr. J. 2002, 49, 211-217. [CrossRef] [PubMed]

5. Poli, A.; Bruschi, F.; Cesana, B.; Rossi, M.; Paoletti, R.; Crosignani, P.G. Plasma low-density lipoprotein cholesterol and bone mass densitometry in postmenopausal women. Obstet. Gynecol. 2003, 102, 922-926. [CrossRef] [PubMed]

6. Tanko, L.B.; Bagger, Y.Z.; Nielsen, S.B.; Christiansen, C. Does serum cholesterol contribute to vertebral bone loss in postmenopausal women? Bone 2003, 32, 8-14. [CrossRef]

7. Adami, S.; Braga, V.; Zamboni, M.; Gatti, D.; Rossini, M.; Bakri, J.; Battaglia, E. Relationship between lipids and bone mass in 2 cohorts of healthy women and men. Calcif. Tissue Int. 2004, 74, 136-142. [CrossRef] [PubMed]

8. Orozco, P. Atherogenic lipid profile and elevated lipoprotein (a) are associated with lower bone mineral density in early postmenopausal overweight women. Eur. J. Epidemiol. 2004, 19, 1105-1112. [CrossRef]

9. Samelson, E.J.; Cupples, L.A.; Hannan, M.T.; Wilson, P.W.; Williams, S.A.; Vaccarino, V.; Zhang, Y.; Kiel, D.P. Long-term effects of serum cholesterol on bone mineral density in women and men: The Framingham Osteoporosis Study. Bone 2004, 34, 557-561. [CrossRef]

10. Cui, L.H.; Shin, M.H.; Chung, E.K.; Lee, Y.H.; Kweon, S.S.; Park, K.S.; Choi, J.S. Association between bone mineral densities and serum lipid profiles of pre- and post-menopausal rural women in South Korea. Osteoporos. Int. 2005, 16, 1975-1981. [CrossRef]

11. Solomon, D.H.; Avorn, J.; Canning, C.F.; Wang, P.S. Lipid levels and bone mineral density. Am. J. Med. 2005, 118, 1414.e1-1414.e5. [CrossRef] [PubMed]

12. Hsu, Y.H.; Venners, S.A.; Terwedow, H.A.; Feng, Y.; Niu, T.; Li, Z.; Laird, N.; Brain, J.D.; Cummings, S.R.; Bouxsein, M.L.; et al. Relation of body composition, fat mass, and serum lipids to osteoporotic fractures and bone mineral density in Chinese men and women. Am. J. Clin. Nutr. 2006, 83, 146-154. [CrossRef] [PubMed]

13. Dennison, E.M.; Syddall, H.E.; Aihie Sayer, A.; Martin, H.J.; Cooper, C.; Hertfordshire Cohort Study Group. Lipid profile, obesity and bone mineral density: The Hertfordshire Cohort Study. QJM 2007, 100, 297-303. [CrossRef] 
14. Tang, Y.J.; Sheu, W.H.; Liu, P.H.; Lee, W.J.; Chen, Y.T. Positive associations of bone mineral density with body mass index, physical activity, and blood triglyceride level in men over 70 years old: A TCVGHAGE study. J. Bone Miner. Metab. 2007, 25, 54-59. [CrossRef] [PubMed]

15. Makovey, J.; Chen, J.S.; Hayward, C.; Williams, F.M.; Sambrook, P.N. Association between serum cholesterol and bone mineral density. Bone 2009, 44, 208-213. [CrossRef] [PubMed]

16. Sivas, F.; Alemdaroglu, E.; Elverici, E.; Kulug, T.; Ozoran, K. Serum lipid profile: Its relationship with osteoporotic vertebrae fractures and bone mineral density in Turkish postmenopausal women. Rheumatol. Int. 2009, 29, 885-890. [CrossRef] [PubMed]

17. Hernandez, J.L.; Olmos, J.M.; Ramos, C.; Martinez, J.; de Juan, J.; Valero, C.; Nan, D.; Gonzalez-Macias, J. Serum lipids and bone metabolism in Spanish men: The Camargo cohort study. Endocr. J. 2010, 57, 51-60. [CrossRef]

18. Go, J.H.; Song, Y.M.; Park, J.H.; Park, J.Y.; Choi, Y.H. Association between Serum Cholesterol Level and Bone Mineral Density at Lumbar Spine and Femur Neck in Postmenopausal Korean Women. Korean J. Fam. Med. 2012, 33, 166-173. [CrossRef]

19. Pliatsika, P.; Antoniou, A.; Alexandrou, A.; Panoulis, C.; Kouskouni, E.; Augoulea, A.; Dendrinos, S.; Aravantinos, L.; Creatsa, M.; Lambrinoudaki, I. Serum lipid levels and bone mineral density in Greek postmenopausal women. Gynecol. Endocrinol. 2012, 28, 655-660. [CrossRef]

20. Kim, Y.H.; Nam, G.E.; Cho, K.H.; Choi, Y.S.; Kim, S.M.; Han, B.D.; Han, K.D.; Lee, K.S.; Park, C.H.; Kim, D.H. Low bone mineral density is associated with dyslipidemia in South Korean men: The 2008-2010 Korean National Health and Nutrition Examination Survey. Endocr. J. 2013, 60, 1179-1189. [CrossRef]

21. Loke, S.S.; Chang, H.W.; Li, W.C. Association between metabolic syndrome and bone mineral density in a Taiwanese elderly population. J. Bone Miner. Metab. 2018, 36, 200-208. [CrossRef]

22. Panahi, N.; Soltani, A.; Ghasem-Zadeh, A.; Shafiee, G.; Heshmat, R.; Razi, F.; Mehrdad, N.; Nabipour, I.; Larijani, B.; Ostovar, A Associations between the lipid profile and the lumbar spine bone mineral density and trabecular bone score in elderly Iranian individuals participating in the Bushehr Elderly Health Program: A population-based study. Arch. Osteoporos. 2019, 14, 52. [CrossRef] [PubMed]

23. Chin, K.Y.; Chan, C.Y.; Subramaniam, S.; Muhammad, N.; Fairus, A.; Ng, P.Y.; Jamil, N.A.; Aziz, N.A.; Ima-Nirwana, S.; Mohamed, N. Positive association between metabolic syndrome and bone mineral density among Malaysians. Int. J. Med. Sci. 2020, 17, 2585-2593. [CrossRef] [PubMed]

24. Zhang, Q.; Zhou, J.; Wang, Q.; Lu, C.; Xu, Y.; Cao, H.; Xie, X.; Wu, X.; Li, J.; Chen, D. Association Between Bone Mineral Density and Lipid Profile in Chinese Women. Clin. Interv. Aging 2020, 15, 1649-1664. [CrossRef] [PubMed]

25. Haring, B.; Crandall, C.J.; Carbone, L.; Liu, S.; Li, W.; Johnson, K.C.; Wactawski-Wende, J.; Shadyab, A.H.; Gass, M.L.; Kamensky, V.; et al. Lipoprotein(a) plasma levels, bone mineral density and risk of hip fracture: A post hoc analysis of the Women's Health Initiative, USA. BMJ Open 2019, 9, e027257. [CrossRef] [PubMed]

26. Chen, Y.Y.; Wang, W.W.; Yang, L.; Chen, W.W.; Zhang, H.X. Association between lipid profiles and osteoporosis in postmenopausal women: A meta-analysis. Eur. Rev. Med. Pharmacol. Sci. 2018, 22, 1-9. [CrossRef]

27. Zhao, H.; Li, Y.; Zhang, M.; Qi, L.; Tang, Y. Blood lipid levels in patients with osteopenia and osteoporosis:a systematic review and meta-analysis. J. Bone Miner. Metab. 2021, 39, 510-520. [CrossRef]

28. Xiao, P.; Hou, D.Q.; Gao, A.Y.; Zhu, Z.X.; Yu, Z.C.; Lin, N.X.; Liu, J.T.; Chang, S.Y.; Mi, J. The association between blood lipids and calcaneus bone mineral density in children and adolescents aged 6-16 years in Beijing. Zhonghua Yu Fang Yi Xue Za Zhi 2019, 53, 196-201. [CrossRef]

29. Ubago-Guisado, E.; Gracia-Marco, L.; Medrano, M.; Cadenas-Sanchez, C.; Arenaza, L.; Migueles, J.H.; Mora-Gonzalez, J.; Tobalina, I.; Escolano-Margarit, M.V.; Oses, M.; et al. Differences in areal bone mineral density between metabolically healthy and unhealthy overweight/obese children: The role of physical activity and cardiorespiratory fitness. Pediatr. Res. 2020, 87, 1219-1225. [CrossRef]

30. Lawlor, D.A.; Sattar, N.; Sayers, A.; Tobias, J.H. The association of fasting insulin, glucose, and lipids with bone mass in adolescents: Findings from a cross-sectional study. J. Clin. Endocrinol. Metab. 2012, 97, 2068-2076. [CrossRef]

31. Thorsen, K.; Nordstrom, P.; Lorentzon, R.; Dahlen, G.H. The relation between bone mineral density, insulin-like growth factor I, lipoprotein (a), body composition, and muscle strength in adolescent males. J. Clin. Endocrinol. Metab. 1999, 84, 3025-3029. [CrossRef] [PubMed]

32. Hetherington-Rauth, M.; Bea, J.W.; Blew, R.M.; Funk, J.L.; Lee, V.R.; Roe, D.J.; Sardinha, L.B.; Going, S.B. Relationship of cardiometabolic risk biomarkers with DXA and pQCT bone health outcomes in young girls. Bone 2019, 120, 452-458. [CrossRef] [PubMed]

33. Sadeghi, O.; Djafarian, K.; Ghorabi, S.; Khodadost, M.; Nasiri, M.; Shab-Bidar, S. Dietary intake of fish, n-3 polyunsaturated fatty acids and risk of hip fracture: A systematic review and meta-analysis on observational studies. Crit. Rev. Food Sci. Nutr. 2019, 59, 1320-1333. [CrossRef]

34. Mandal, C.C. High Cholesterol Deteriorates Bone Health: New Insights into Molecular Mechanisms. Front. Endocrinol. 2015, 6, 165. [CrossRef] [PubMed]

35. Pelton, K.; Krieder, J.; Joiner, D.; Freeman, M.R.; Goldstein, S.A.; Solomon, K.R. Hypercholesterolemia promotes an osteoporotic phenotype. Am. J. Pathol. 2012, 181, 928-936. [CrossRef] [PubMed]

36. Papachristou, N.I.; Blair, H.C.; Kypreos, K.E.; Papachristou, D.J. High-density lipoprotein (HDL) metabolism and bone mass. J. Endocrinol. 2017, 233, R95-R107. [CrossRef] [PubMed] 
37. Tintut, Y.; Demer, L.L. Effects of bioactive lipids and lipoproteins on bone. Trends Endocrinol. Metab. 2014, 25, 53-59. [CrossRef]

38. Ambrogini, E.; Que, X.; Wang, S.; Yamaguchi, F.; Weinstein, R.S.; Tsimikas, S.; Manolagas, S.C.; Witztum, J.L.; Jilka, R.L. Oxidation-specific epitopes restrain bone formation. Nat. Commun. 2018, 9, 2193. [CrossRef]

39. Demer, L.L. Vascular calcification and osteoporosis: Inflammatory responses to oxidized lipids. Int. J. Epidemiol. 2002, 31, 737-741. [CrossRef]

40. Tian, L.; Yu, X. Lipid metabolism disorders and bone dysfunction—Interrelated and mutually regulated (review). Mol. Med. Rep. 2015, 12, 783-794. [CrossRef]

41. Tintut, Y.; Parhami, F.; Tsingotjidou, A.; Tetradis, S.; Territo, M.; Demer, L.L. 8-Isoprostaglandin E2 enhances receptor-activated NFkappa B ligand (RANKL)-dependent osteoclastic potential of marrow hematopoietic precursors via the cAMP pathway. J. Biol. Chem. 2002, 277, 14221-14226. [CrossRef] [PubMed]

42. McFarlane, S.I.; Muniyappa, R.; Shin, J.J.; Bahtiyar, G.; Sowers, J.R. Osteoporosis and cardiovascular disease: Brittle bones and boned arteries, is there a link? Endocrine 2004, 23, 1-10. [CrossRef]

43. Zeng, X.; Zhan, K.; Zhang, L.; Zeng, D.; Yu, W.; Zhang, X.; Zhao, M.; Lai, Z.; Chen, R. The impact of high total cholesterol and high low-density lipoprotein on avascular necrosis of the femoral head in low-energy femoral neck fractures. J. Orthop. Surg. Res. 2017, 12, 30. [CrossRef] [PubMed]

44. Losordo, D.W.; Kearney, M.; Kim, E.A.; Jekanowski, J.; Isner, J.M. Variable expression of the estrogen receptor in normal and atherosclerotic coronary arteries of premenopausal women. Circulation 1994, 89, 1501-1510. [CrossRef]

45. Anagnostis, P.; Bosdou, J.K.; Vaitsi, K.; Goulis, D.G.; Lambrinoudaki, I. Estrogen and bones after menopause: A reappraisal of data and future perspectives. Hormones 2021, 20, 13-21. [CrossRef] [PubMed]

46. Anagnostis, P.; Stevenson, J.C.; Crook, D.; Johnston, D.G.; Godsland, I.F. Effects of menopause, gender and age on lipids and high-density lipoprotein cholesterol subfractions. Maturitas 2015, 81, 62-68. [CrossRef] [PubMed]

47. Anagnostis, P.; Stevenson, J.C.; Crook, D.; Johnston, D.G.; Godsland, I.F. Effects of gender, age and menopausal status on serum apolipoprotein concentrations. Clin. Endocrinol. 2016, 85, 733-740. [CrossRef]

48. Khosla, S.; Atkinson, E.J.; Melton, L.J., 3rd; Riggs, B.L. Effects of age and estrogen status on serum parathyroid hormone levels and biochemical markers of bone turnover in women: A population-based study. J. Clin. Endocrinol. Metab. 1997, 82, $1522-1527$. [CrossRef]

49. Stefenelli, T.; Mayr, H.; Bergler-Klein, J.; Globits, S.; Woloszczuk, W.; Niederle, B. Primary hyperparathyroidism: Incidence of cardiac abnormalities and partial reversibility after successful parathyroidectomy. Am. J. Med. 1993, 95, 197-202. [CrossRef]

50. Ray, M.; Jovanovich, A. Mineral Bone Abnormalities and Vascular Calcifications. Adv. Chronic Kidney Dis. 2019, 26, 409-416. [CrossRef]

51. Lips, P. Vitamin D deficiency and secondary hyperparathyroidism in the elderly: Consequences for bone loss and fractures and therapeutic implications. Endocr. Rev. 2001, 22, 477-501. [CrossRef]

52. Anagnostis, P.; Athyros, V.G.; Adamidou, F.; Florentin, M.; Karagiannis, A. Vitamin D and cardiovascular disease: A novel agent for reducing cardiovascular risk? Curr. Vasc. Pharmacol. 2010, 8, 720-730. [CrossRef] [PubMed]

53. Laroche, M.; Pecourneau, V.; Blain, H.; Breuil, V.; Chapurlat, R.; Cortet, B.; Sutter, B.; Degboe, Y. Osteoporosis and ischemic cardiovascular disease. Jt. Bone Spine 2017, 84, 427-432. [CrossRef] [PubMed]

54. Agca, R.; Heslinga, S.C.; Rollefstad, S.; Heslinga, M.; McInnes, I.B.; Peters, M.J.; Kvien, T.K.; Dougados, M.; Radner, H.; Atzeni, F.; et al. EULAR recommendations for cardiovascular disease risk management in patients with rheumatoid arthritis and other forms of inflammatory joint disorders: 2015/2016 update. Ann. Rheum. Dis. 2017, 76, 17-28. [CrossRef] [PubMed]

55. Hofbauer, L.C.; Brueck, C.C.; Shanahan, C.M.; Schoppet, M.; Dobnig, H. Vascular calcification and osteoporosis-From clinical observation towards molecular understanding. Osteoporos. Int. 2007, 18, 251-259. [CrossRef]

56. Luo, G.; Ducy, P.; McKee, M.D.; Pinero, G.J.; Loyer, E.; Behringer, R.R.; Karsenty, G. Spontaneous calcification of arteries and cartilage in mice lacking matrix GLA protein. Nature 1997, 386, 78-81. [CrossRef] [PubMed]

57. Price, P.A.; Williamson, M.K.; Haba, T.; Dell, R.B.; Jee, W.S. Excessive mineralization with growth plate closure in rats on chronic warfarin treatment. Proc. Natl. Acad. Sci. USA 1982, 79, 7734-7738. [CrossRef]

58. Shanahan, C.M.; Proudfoot, D.; Tyson, K.L.; Cary, N.R.; Edmonds, M.; Weissberg, P.L. Expression of mineralisation-regulating proteins in association with human vascular calcification. Z. Kardiol. 2000, 89 (Suppl. 2), 63-68. [CrossRef]

59. Dhore, C.R.; Cleutjens, J.P.; Lutgens, E.; Cleutjens, K.B.; Geusens, P.P.; Kitslaar, P.J.; Tordoir, J.H.; Spronk, H.M.; Vermeer, C.; Daemen, M.J. Differential expression of bone matrix regulatory proteins in human atherosclerotic plaques. Arterioscler. Thromb. Vasc. Biol. 2001, 21, 1998-2003. [CrossRef]

60. Lane, N.E.; Sanchez, S.; Genant, H.K.; Jenkins, D.K.; Arnaud, C.D. Short-term increases in bone turnover markers predict parathyroid hormone-induced spinal bone mineral density gains in postmenopausal women with glucocorticoid-induced osteoporosis. Osteoporos. Int. 2000, 11, 434-442. [CrossRef]

61. Bini, A.; Mann, K.G.; Kudryk, B.J.; Schoen, F.J. Noncollagenous bone matrix proteins, calcification, and thrombosis in carotid artery atherosclerosis. Arterioscler. Thromb. Vasc. Biol. 1999, 19, 1852-1861. [CrossRef] [PubMed]

62. Stojanovic, O.I.; Lazovic, M.; Lazovic, M.; Vuceljic, M. Association between atherosclerosis and osteoporosis, the role of vitamin D. Arch. Med. Sci. 2011, 7, 179-188. [CrossRef] [PubMed]

63. Hynes, R.O. Integrins: Bidirectional, allosteric signaling machines. Cell 2002, 110, 673-687. [CrossRef] 
64. Reinholt, F.P.; Hultenby, K.; Oldberg, A.; Heinegard, D. Osteopontin-A possible anchor of osteoclasts to bone. Proc. Natl. Acad. Sci. USA 1990, 87, 4473-4475. [CrossRef] [PubMed]

65. Ross, F.P.; Chappel, J.; Alvarez, J.I.; Sander, D.; Butler, W.T.; Farach-Carson, M.C.; Mintz, K.A.; Robey, P.G.; Teitelbaum, S.L.; Cheresh, D.A. Interactions between the bone matrix proteins osteopontin and bone sialoprotein and the osteoclast integrin alpha v beta 3 potentiate bone resorption. J. Biol. Chem. 1993, 268, 9901-9907. [CrossRef]

66. Chellaiah, M.A.; Soga, N.; Swanson, S.; McAllister, S.; Alvarez, U.; Wang, D.; Dowdy, S.F.; Hruska, K.A. Rho-A is critical for osteoclast podosome organization, motility, and bone resorption. J. Biol. Chem. 2000, 275, 11993-12002. [CrossRef]

67. Scatena, M.; Liaw, L.; Giachelli, C.M. Osteopontin: A multifunctional molecule regulating chronic inflammation and vascular disease. Arterioscler. Thromb. Vasc. Biol. 2007, 27, 2302-2309. [CrossRef]

68. Abdalrhim, A.D.; Marroush, T.S.; Austin, E.E.; Gersh, B.J.; Solak, N.; Rizvi, S.A.; Bailey, K.R.; Kullo, I.J. Plasma Osteopontin Levels and Adverse Cardiovascular Outcomes in the PEACE Trial. PLoS ONE 2016, 11, e0156965. [CrossRef]

69. Fitzpatrick, L.A.; Severson, A.; Edwards, W.D.; Ingram, R.T. Diffuse calcification in human coronary arteries. Association of osteopontin with atherosclerosis. J. Clin. Investig. 1994, 94, 1597-1604. [CrossRef]

70. Polonskaya, Y.V.; Kashtanova, E.V.; Murashov, I.S.; Kurguzov, A.V.; Sadovski, E.V.; Maslatsov, N.A.; Stakhneva, E.M.; Chernyavskii, A.M.; Ragino, Y.I. The Influence of Calcification Factors and Endothelial-Dysfunction Factors on the Development of Unstable Atherosclerotic Plaques. Diagnostics 2020, 10, 1074. [CrossRef]

71. Srivatsa, S.S.; Harrity, P.J.; Maercklein, P.B.; Kleppe, L.; Veinot, J.; Edwards, W.D.; Johnson, C.M.; Fitzpatrick, L.A. Increased cellular expression of matrix proteins that regulate mineralization is associated with calcification of native human and porcine xenograft bioprosthetic heart valves. J. Clin. Investig. 1997, 99, 996-1009. [CrossRef] [PubMed]

72. Steitz, S.A.; Speer, M.Y.; Curinga, G.; Yang, H.Y.; Haynes, P.; Aebersold, R.; Schinke, T.; Karsenty, G.; Giachelli, C.M. Smooth muscle cell phenotypic transition associated with calcification: Upregulation of Cbfa1 and downregulation of smooth muscle lineage markers. Circ. Res. 2001, 89, 1147-1154. [CrossRef] [PubMed]

73. Leali, D.; Dell'Era, P.; Stabile, H.; Sennino, B.; Chambers, A.F.; Naldini, A.; Sozzani, S.; Nico, B.; Ribatti, D.; Presta, M. Osteopontin (Eta-1) and fibroblast growth factor-2 cross-talk in angiogenesis. J. Immunol. 2003, 171, 1085-1093. [CrossRef] [PubMed]

74. Chen, D.; Zhao, M.; Mundy, G.R. Bone morphogenetic proteins. Growth Factors 2004, 22, 233-241. [CrossRef] [PubMed]

75. Wu, M.; Chen, G.; Li, Y.P. TGF-beta and BMP signaling in osteoblast, skeletal development, and bone formation, homeostasis and disease. Bone Res. 2016, 4, 16009. [CrossRef]

76. Sieber, C.; Kopf, J.; Hiepen, C.; Knaus, P. Recent advances in BMP receptor signaling. Cytokine Growth Factor Rev. 2009, 20, 343-355. [CrossRef]

77. Dyer, L.A.; Pi, X.; Patterson, C. The role of BMPs in endothelial cell function and dysfunction. Trends Endocrinol. Metab. 2014, 25, 472-480. [CrossRef]

78. Sipe, J.B.; Zhang, J.; Waits, C.; Skikne, B.; Garimella, R.; Anderson, H.C. Localization of bone morphogenetic proteins (BMPs)-2, -4, and -6 within megakaryocytes and platelets. Bone 2004, 35, 1316-1322. [CrossRef]

79. Jank, M.; von Niessen, N.; Olivier, C.B.; Schmitt, H.; Anto-Michel, N.; Hilgendorf, I.; Bode, C.; Moser, M.; Esser, J.S.; Zhou, Q. Platelet Bone Morphogenetic Protein-4 Mediates Vascular Inflammation and Neointima Formation after Arterial Injury. Cells 2021, 10, 2027. [CrossRef]

80. Engelse, M.A.; Neele, J.M.; Bronckers, A.L.; Pannekoek, H.; de Vries, C.J. Vascular calcification: Expression patterns of the osteoblast-specific gene core binding factor alpha-1 and the protective factor matrix gla protein in human atherogenesis. Cardiovasc. Res. 2001, 52, 281-289. [CrossRef]

81. Shao, J.S.; Cheng, S.L.; Pingsterhaus, J.M.; Charlton-Kachigian, N.; Loewy, A.P.; Towler, D.A. Msx2 promotes cardiovascular calcification by activating paracrine Wnt signals. J. Clin. Investig. 2005, 115, 1210-1220. [CrossRef] [PubMed]

82. Vacek, T.P.; Kalani, A.; Voor, M.J.; Tyagi, S.C.; Tyagi, N. The role of homocysteine in bone remodeling. Clin. Chem. Lab. Med. 2013, 51, 579-590. [CrossRef]

83. Tyagi, N.; Vacek, T.P.; Fleming, J.T.; Vacek, J.C.; Tyagi, S.C. Hyperhomocysteinemia decreases bone blood flow. Vasc. Health Risk Manag. 2011, 7, 31-35. [CrossRef] [PubMed]

84. Rumbak, I.; Zizic, V.; Sokolic, L.; Cvijetic, S.; Kajfez, R.; Colic Baric, I. Bone mineral density is not associated with homocysteine level, folate and vitamin B12 status. Arch. Gynecol. Obstet. 2012, 285, 991-1000. [CrossRef] [PubMed]

85. Ahn, T.K.; Kim, J.O.; An, H.J.; Park, H.S.; Choi, U.Y.; Sohn, S.; Kim, K.T.; Kim, N.K.; Han, I.B. 3'-UTR Polymorphisms of Vitamin B-Related Genes Are Associated with Osteoporosis and Osteoporotic Vertebral Compression Fractures (OVCFs) in Postmenopausal Women. Genes 2020, 11, 612. [CrossRef] [PubMed]

86. Enneman, A.W.; Swart, K.M.; van Wijngaarden, J.P.; van Dijk, S.C.; Ham, A.C.; Brouwer-Brolsma, E.M.; van der Zwaluw, N.L.; Dhonukshe-Rutten, R.A.; van der Cammen, T.J.; de Groot, L.C.; et al. Effect of Vitamin B12 and Folic Acid Supplementation on Bone Mineral Density and Quantitative Ultrasound Parameters in Older People with an Elevated Plasma Homocysteine Level: B-PROOF, a Randomized Controlled Trial. Calcif. Tissue Int. 2015, 96, 401-409. [CrossRef] [PubMed]

87. Tawakol, A.; Omland, T.; Gerhard, M.; Wu, J.T.; Creager, M.A. Hyperhomocyst(e)inemia is associated with impaired endotheliumdependent vasodilation in humans. Circulation 1997, 95, 1119-1121. [CrossRef]

88. Santilli, F.; Davi, G.; Patrono, C. Homocysteine, methylenetetrahydrofolate reductase, folate status and atherothrombosis: A mechanistic and clinical perspective. Vascul. Pharmacol. 2016, 78, 1-9. [CrossRef] 
89. Momin, M.; Jia, J.; Fan, F.; Li, J.; Dou, J.; Chen, D.; Huo, Y.; Zhang, Y. Relationship between plasma homocysteine level and lipid profiles in a community-based Chinese population. Lipids Health Dis. 2017, 16, 54. [CrossRef]

90. Li, H.; Forstermann, U. Prevention of atherosclerosis by interference with the vascular nitric oxide system. Curr. Pharm. Des. 2009, 15, 3133-3145. [CrossRef]

91. Li, H.; Forstermann, U. Nitric oxide in the pathogenesis of vascular disease. J. Pathol. 2000, 190, 244-254. [CrossRef]

92. Forstermann, U.; Sessa, W.C. Nitric oxide synthases: Regulation and function. Eur. Heart J. 2012, 33, 829-837. [CrossRef] [PubMed]

93. Saura, M.; Tarin, C.; Zaragoza, C. Recent insights into the implication of nitric oxide in osteoblast differentiation and proliferation during bone development. Sci. World J. 2010, 10, 624-632. [CrossRef] [PubMed]

94. Wimalawansa, S.J. Rationale for using nitric oxide donor therapy for prevention of bone loss and treatment of osteoporosis in humans. Ann. N. Y. Acad. Sci. 2007, 1117, 283-297. [CrossRef]

95. Boyce, B.F.; Xing, L. Functions of RANKL/RANK/OPG in bone modeling and remodeling. Arch. Biochem. Biophys. 2008, 473, 139-146. [CrossRef] [PubMed]

96. Kim, J.H.; Kim, N. Regulation of NFATc1 in Osteoclast Differentiation. J. Bone Metab. 2014, 21, 233-241. [CrossRef] [PubMed]

97. Baud'huin, M.; Duplomb, L.; Teletchea, S.; Lamoureux, F.; Ruiz-Velasco, C.; Maillasson, M.; Redini, F.; Heymann, M.F.; Heymann, D. Osteoprotegerin: Multiple partners for multiple functions. Cytokine Growth Factor Rev. 2013, 24, 401-409. [CrossRef]

98. Simonet, W.S.; Lacey, D.L.; Dunstan, C.R.; Kelley, M.; Chang, M.S.; Luthy, R.; Nguyen, H.Q.; Wooden, S.; Bennett, L.; Boone, T.; et al. Osteoprotegerin: A novel secreted protein involved in the regulation of bone density. Cell 1997, 89, 309-319. [CrossRef]

99. Kawakami, R.; Nakagami, H.; Noma, T.; Ohmori, K.; Kohno, M.; Morishita, R. RANKL system in vascular and valve calcification with aging. Inflamm. Regen. 2016, 36, 10. [CrossRef]

100. Nusse, R.; Clevers, H. Wnt/beta-Catenin Signaling, Disease, and Emerging Therapeutic Modalities. Cell 2017, 169, 985-999. [CrossRef]

101. Tamai, K.; Semenov, M.; Kato, Y.; Spokony, R.; Liu, C.; Katsuyama, Y.; Hess, F.; Saint-Jeannet, J.P.; He, X. LDL-receptor-related proteins in Wnt signal transduction. Nature 2000, 407, 530-535. [CrossRef] [PubMed]

102. Bienz, M. TCF: Transcriptional activator or repressor? Curr. Opin. Cell Biol. 1998, 10, 366-372. [CrossRef]

103. Boucher, P.; Matz, R.L.; Terrand, J. atherosclerosis: Gone with the Wnt? Atherosclerosis 2020, 301, 15-22. [CrossRef] [PubMed]

104. Mikhaylova, L.; Malmquist, J.; Nurminskaya, M. Regulation of in vitro vascular calcification by BMP4, VEGF and Wnt3a. Calcif. Tissue Int. 2007, 81, 372-381. [CrossRef] [PubMed]

105. Manolagas, S.C.; Almeida, M. Gone with the Wnts: Beta-catenin, T-cell factor, forkhead box O, and oxidative stress in agedependent diseases of bone, lipid, and glucose metabolism. Mol. Endocrinol. 2007, 21, 2605-2614. [CrossRef] [PubMed]

106. Wehmeyer, C.; Frank, S.; Beckmann, D.; Bottcher, M.; Cromme, C.; Konig, U.; Fennen, M.; Held, A.; Paruzel, P.; Hartmann, C.; et al. Sclerostin inhibition promotes TNF-dependent inflammatory joint destruction. Sci. Transl. Med. 2016, 8, 330ra335. [CrossRef] [PubMed]

107. Gaudio, A.; Fiore, V.; Rapisarda, R.; Sidoti, M.H.; Xourafa, A.; Catalano, A.; Tringali, G.; Zanoli, L.; Signorelli, S.S.; Fiore, C.E. Sclerostin is a possible candidate marker of arterial stiffness: Results from a cohort study in Catania. Mol. Med. Rep. 2017, 15, 3420-3424. [CrossRef] [PubMed]

108. Banerjee, C.; McCabe, L.R.; Choi, J.Y.; Hiebert, S.W.; Stein, J.L.; Stein, G.S.; Lian, J.B. Runt homology domain proteins in osteoblast differentiation: AML3/CBFA1 is a major component of a bone-specific complex. J. Cell. Biochem. 1997, 66, 1-8. [CrossRef]

109. Byon, C.H.; Javed, A.; Dai, Q.; Kappes, J.C.; Clemens, T.L.; Darley-Usmar, V.M.; McDonald, J.M.; Chen, Y. Oxidative stress induces vascular calcification through modulation of the osteogenic transcription factor Runx2 by AKT signaling. J. Biol. Chem. 2008, 283, 15319-15327. [CrossRef] [PubMed]

110. Anagnostis, P.; Vaitsi, K.; Kleitsioti, P.; Mantsiou, C.; Pavlogiannis, K.; Athyros, V.G.; Mikhailidis, D.P.; Goulis, D.G. Efficacy and safety of statin use in children and adolescents with familial hypercholesterolaemia: A systematic review and meta-analysis of randomized-controlled trials. Endocrine 2020, 69, 249-261. [CrossRef] [PubMed]

111. Athyros, V.G.; Katsiki, N.; Tziomalos, K.; Gossios, T.D.; Theocharidou, E.; Gkaliagkousi, E.; Anagnostis, P.; Pagourelias, E.D.; Karagiannis, A.; Mikhailidis, D.P.; et al. Statins and cardiovascular outcomes in elderly and younger patients with coronary artery disease: A post hoc analysis of the GREACE study. Arch. Med. Sci. 2013, 9, 418-426. [CrossRef] [PubMed]

112. Siperstein, M.D.; Fagan, V.M. Feedback control of mevalonate synthesis by dietary cholesterol. J. Biol. Chem. 1966, 241, 602-609. [CrossRef]

113. Anagnostis, P.; Stevenson, J.C. Bisphosphonate drug holidays-When, why and for how long? Climacteric 2015, 18 (Suppl. 2), 32-38. [CrossRef] [PubMed]

114. Moon, H.J.; Kim, S.E.; Yun, Y.P.; Hwang, Y.S.; Bang, J.B.; Park, J.H.; Kwon, I.K. Simvastatin inhibits osteoclast differentiation by scavenging reactive oxygen species. Exp. Mol. Med. 2011, 43, 605-612. [CrossRef]

115. Mundy, G.; Garrett, R.; Harris, S.; Chan, J.; Chen, D.; Rossini, G.; Boyce, B.; Zhao, M.; Gutierrez, G. Stimulation of bone formation in vitro and in rodents by statins. Science 1999, 286, 1946-1949. [CrossRef]

116. Weivoda, M.M.; Hohl, R.J. Effects of farnesyl pyrophosphate accumulation on calvarial osteoblast differentiation. Endocrinology 2011, 152, 3113-3122. [CrossRef]

117. Qiao, L.J.; Kang, K.L.; Heo, J.S. Simvastatin promotes osteogenic differentiation of mouse embryonic stem cells via canonical Wnt/beta-catenin signaling. Mol. Cells 2011, 32, 437-444. [CrossRef] 
118. Wang, Z.; Li, Y.; Zhou, F.; Piao, Z.; Hao, J. Effects of Statins on Bone Mineral Density and Fracture Risk: A PRISMA-compliant Systematic Review and Meta-Analysis. Medicine 2016, 95, e3042. [CrossRef]

119. An, T.; Hao, J.; Sun, S.; Li, R.; Yang, M.; Cheng, G.; Zou, M. Efficacy of statins for osteoporosis: A systematic review and meta-analysis. Osteoporos. Int. 2017, 28, 47-57. [CrossRef]

120. Zheng, J.; Brion, M.J.; Kemp, J.P.; Warrington, N.M.; Borges, M.C.; Hemani, G.; Richardson, T.G.; Rasheed, H.; Qiao, Z.; Haycock P.; et al. The Effect of Plasma Lipids and Lipid-Lowering Interventions on Bone Mineral Density: A Mendelian Randomization Study. J. Bone Miner. Res. 2020, 35, 1224-1235. [CrossRef]

121. Shi, R.; Mei, Z.; Zhang, Z.; Zhu, Z. Effects of Statins on Relative Risk of Fractures for Older Adults: An Updated Systematic Review with Meta-Analysis. J. Am. Med. Dir. Assoc. 2019, 20, 1566-1578.e3. [CrossRef] [PubMed]

122. Phan, B.A.; Dayspring, T.D.; Toth, P.P. Ezetimibe therapy: Mechanism of action and clinical update. Vasc. Health Risk Manag. 2012, 8, 415-427. [CrossRef] [PubMed]

123. Reboul, E.; Goncalves, A.; Comera, C.; Bott, R.; Nowicki, M.; Landrier, J.F.; Jourdheuil-Rahmani, D.; Dufour, C.; Collet, X.; Borel, P. Vitamin D intestinal absorption is not a simple passive diffusion: Evidences for involvement of cholesterol transporters. Mol. Nutr. Food Res. 2011, 55, 691-702. [CrossRef] [PubMed]

124. Kiourtzidis, M.; Kuhn, J.; Schutkowski, A.; Baur, A.C.; Hirche, F.; Stangl, G.I. Inhibition of Niemann-Pick C1-like protein 1 by ezetimibe reduces uptake of deuterium-labeled vitamin D in mice. J. Steroid Biochem. Mol. Biol. 2020, 197, 105504. [CrossRef]

125. Silva, M.C.; Faulhauber, G.A.M.; Leite, E.N.; Goulart, K.R.; Ramirez, J.M.A.; Cocolichio, F.M.; Furlanetto, T.W. Impact of a cholesterol membrane transporter's inhibition on vitamin D absorption: A double-blind randomized placebo-controlled study. Bone 2015, 81, 338-342. [CrossRef]

126. Sertbas, Y.; Ersoy, U.; Ayter, M.; Gultekin Tirtil, F.; Kucukkaya, B. Ezetimibe effect on bone mineral density and markers of bone formation and resorption. J. Investig. Med. 2010, 58, 295-297. [CrossRef]

127. Mach, F.; Baigent, C.; Catapano, A.L.; Koskinas, K.C.; Casula, M.; Badimon, L.; Chapman, M.J.; De Backer, G.G.; Delgado, V.; Ference, B.A.; et al. 2019 ESC/EAS Guidelines for the management of dyslipidaemias: Lipid modification to reduce cardiovascular risk. Eur. Heart J. 2020, 41, 111-188. [CrossRef]

128. Kim, Y.H.; Jang, W.G.; Oh, S.H.; Kim, J.W.; Lee, M.N.; Song, J.H.; Yang, J.W.; Zang, Y.; Koh, J.T. Fenofibrate induces PPARalpha and BMP2 expression to stimulate osteoblast differentiation. Biochem. Biophys. Res. Commun. 2019, 520, 459-465. [CrossRef]

129. Stunes, A.K.; Westbroek, I.; Gustafsson, B.I.; Fossmark, R.; Waarsing, J.H.; Eriksen, E.F.; Petzold, C.; Reseland, J.E.; Syversen, U. The peroxisome proliferator-activated receptor (PPAR) alpha agonist fenofibrate maintains bone mass, while the PPAR gamma agonist pioglitazone exaggerates bone loss, in ovariectomized rats. BMC Endocr. Disord. 2011, 11, 11. [CrossRef]

130. Shi, T.; Lu, K.; Shen, S.; Tang, Q.; Zhang, K.; Zhu, X.; Shi, Y.; Liu, X.; Teng, H.; Li, C.; et al. Fenofibrate decreases the bone quality by down regulating Runx2 in high-fat-diet induced Type 2 diabetes mellitus mouse model. Lipids Health Dis. 2017, 16, 201. [CrossRef]

131. Rejnmark, L.; Vestergaard, P.; Mosekilde, L. Statin but not non-statin lipid-lowering drugs decrease fracture risk: A nation-wide case-control study. Calcif. Tissue Int. 2006, 79, 27-36. [CrossRef] [PubMed]

132. Li, Y.; Seifert, M.F.; Ney, D.M.; Grahn, M.; Grant, A.L.; Allen, K.G.; Watkins, B.A. Dietary conjugated linoleic acids alter serum IGF-I and IGF binding protein concentrations and reduce bone formation in rats fed (n-6) or (n-3) fatty acids. J. Bone Miner. Res. 1999, 14, 1153-1162. [CrossRef] [PubMed]

133. Iwami-Morimoto, Y.; Yamaguchi, K.; Tanne, K. Influence of dietary n-3 polyunsaturated fatty acid on experimental tooth movement in rats. Angle Orthod. 1999, 69, 365-371. [CrossRef] [PubMed]

134. Chen, Y.; Cao, H.; Sun, D.; Lin, C.; Wang, L.; Huang, M.; Jiang, H.; Zhang, Z.; Jin, D.; Zhang, B.; et al. Endogenous Production of n-3 Polyunsaturated Fatty Acids Promotes Fracture Healing in Mice. J. Healthc. Eng. 2017, 2017, 3571267. [CrossRef] [PubMed]

135. Orchard, T.S.; Pan, X.; Cheek, F.; Ing, S.W.; Jackson, R.D. A systematic review of omega-3 fatty acids and osteoporosis. Br. J. Nutr. 2012, 107 (Suppl. 2), S253-S260. [CrossRef] [PubMed]

136. Abdelhamid, A.; Hooper, L.; Sivakaran, R.; Hayhoe, R.P.G.; Welch, A.; Group, P. The Relationship Between Omega-3, Omega-6 and Total Polyunsaturated Fat and Musculoskeletal Health and Functional Status in Adults: A Systematic Review and Meta-analysis of RCTs. Calcif. Tissue Int. 2019, 105, 353-372. [CrossRef]

137. Carbone, L.D.; Buzkova, P.; Fink, H.A.; Raiford, M.; Le, B.; Isales, C.M.; Shikany, J.M.; Coughlin, S.S.; Robbins, J.A. Association of Dietary Niacin Intake with Incident Hip Fracture, BMD, and Body Composition: The Cardiovascular Health Study. J. Bone Miner. Res. 2019, 34, 643-652. [CrossRef]

138. Sasaki, S.; Yanagibori, R. Association between current nutrient intakes and bone mineral density at calcaneus in pre- and postmenopausal Japanese women. J. Nutr. Sci. Vitaminol. 2001, 47, 289-294. [CrossRef]

139. Ismail, F.; Corder, C.N.; Epstein, S.; Barbi, G.; Thomas, S. Effects of pravastatin and cholestyramine on circulating levels of parathyroid hormone and vitamin D metabolites. Clin. Ther. 1990, 12, 427-430. 